\title{
The Relation Of Hormonal Contraception Use With Obesity In Women Of Childbearing Age (WUS) Of Public Health Insurance Participants In The Lamongan Clinic
}

\author{
Asyaul Wasiah* \\ University of Islamic Lamongan, Indonesia \\ *asyaulwasiah@unisla.ac.id
}

\begin{abstract}
Obesity is caused by several factors, one of them is the use of contraception in particular the use of hormonal contraceptives that its use can cause various side effects such as changes in body weight-acceptor.

The research aims to determine the relation of hormonal contraception use with obesity in women of childbearing age (WUS) of public health insurance participants in the Lamongan clinic. This study is an Observational Analytics with cross-sectional. The total sample of 77 respondents. The respondents who use hormonal contraception are 49 respondents while the respondents who did not use contraception are 28 respondents. The respondents who use hormonal contraception and were obese are 22 respondents. Conclusion: The type of contraception most widely used by women of childbearing age is hormonal contraceptives and there is no relationship between the use of contraception with obesity in women of childbearing age at Lamongan clinic.
\end{abstract}

Keywords : Hormonal Contraception, Obesity, Women 


\section{STRADA Jurnal Ilmiah Kesehatan}

DOI: $10.30994 /$ sjik.v9i2.249

ISSN: 2252-3847 (print); 2614-350X (online)

Vol.9 No.2 November 2020 Page.964-969

\section{BACKGROUND}

Indonesia is a developing country with various types of problems faced, one of which is population, which is still high population growth. The National Population and Family Planning Board revealed that Indonesia's population in 2011 could reach 241 million, whereas the government's target for 2013 was only 243 million. Indonesia's population growth is estimated to reach $4.9 \%$ annually, therefore the BKKBN seeks to reduce the high population growth rate by inviting all parties to work hard in controlling population growth using family planning or contraception methods.

Contraception is an effort to prevent pregnancy. Efforts can be temporary, can also be permanent. Use of contraception is one of the variables that affect fertility

The use of hormonal contraception is often avoided in obese or overweight women because of the questionable side effects and effectiveness. Hormonal contraception is very often used and also has a very satisfying success rate for delaying pregnancy or as an emergency contraception. Hormonal contraception consists of progestrons or a combination of estrogen and progesterone. Hormonal contraception is available in the form of pills, implants, injections, or contraception in the womb (IUD). Contraception pills are the most widely used. Hormonal contraception has several side effects, namely mood swings, headaches, decreased libido, mastalgia, acne, menorrhagia, nausea, and weight gain. Estrogen contraception can also increase the risk of venous thromboembolism

Weight gain is one of the most commonly reported side effects of hormonal contraception. This often causes the use of hormonal contraception to be avoided, especially for women with obesity to prevent further weight gain

Hormonal contraception is considered to increase body weight by increasing body fat levels and fluid retention. However, studies show that weight changes due to contraceptive use have not been established. Existing research still shows many other triggering factors (confounders). The relationship between hormone dosage with weight gain was also not found. Obesity is caused by several factors, including: genetic, energy intake, physical activity, the environment, psychological, socioeconomic status and the use of contraception, especially hormonal contraception. The family planning program has the dual purpose of reducing birth rates and realizing the norm of happy and prosperous small families. However, it cannot be denied that there are other consequences of using contraceptives, especially hormonal contraception. This can cause various side effects including changes in acceptor weight. This is caused by the hormone progesterone facilitating the conversion of carbohydrates and sugars into fat, so that fat under the skin increases. Based on this, the authors are interested in examining how the relationship between contraceptive use and obesity in women of childbearing age

\section{METHODS}

The design of this research was analytic observational with cross-sectional research design. The place and time of the study was conducted in December 2019 to January 2020 at the Lamongan Health Center. The independent variable (hormonal contraception), the dependent variable (obesity).

The population is all women of childbearing age (WUS) aged 18-49 years as many as 325 people. Sampling based on Purposive Sampling method obtained a sample of 77 people. Statistical analysis using the Chi Square test. 


\section{STRADA Jurnal Ilmiah Kesehatan}

DOI: $10.30994 /$ sjik.v9i2.249

ISSN: 2252-3847 (print); 2614-350X (online)

Vol.9 No.2 November 2020 Page.964-969

\section{RESULT}

In this study the description of the nutritional status of respondents was only taken into two categories, namely obesity and not obesity. The data can be seen in the table below:

Table 1. Description of respondent's nutrition status

\begin{tabular}{lcc}
\hline \multicolumn{1}{c}{ Nutrition Status } & $\mathbf{N}$ & \% \\
\hline Obesity & 32 & 41,6 \\
Not Obesity & 45 & 58,4 \\
Total & 77 & 100 \\
\hline
\end{tabular}

Based on the table above shows that the number of respondents with Obesity nutritional status as many as 32 people with a percentage of $41.6 \%$ and No Obesity as many as 45 people with a percentage of $58.4 \%$.

Table 2. Distribution of subjects is based on the use of hormonal contraception

\begin{tabular}{llc}
\hline \multicolumn{1}{r}{ Contraception } & N & \% \\
\hline Yes & 49 & 63,6 \\
No & 28 & 36,4 \\
Total & 77 & 100 \\
\hline
\end{tabular}

The results obtained illustrate the use of hormonal contraception, from 77 research subjects there were 49 people (63.6\%) who used contraception and 28 people (36.4\%) did not use contraception.

Bivariate analysis in this study was conducted to prove the hypothesis about the relationship between contraceptive use and obesity in women of childbearing age (WUS) using the Chi-Square test. The test results show a cross table between the use of hormonal contraception and obesity

Table 3. The relationship of hormonal contraceptive use with obesity in WUS

\begin{tabular}{lcccc} 
Contraception & \multicolumn{2}{c}{ Nutrition Status } & Total & P \\
Obesity & No Obesity & & \\
Yes & 22 & 27 & 49 & \\
No & 10 & 18 & 28 & 0,585 \\
Total & 32 & 45 & 77 & \\
\hline
\end{tabular}

Based on the results of statistical tests using Chi-square values obtained $\mathrm{P}=0.585$ > $\alpha=0.05$. These results indicate that there is no relationship between contraceptive use and obesity in women of childbearing age (WUS) in the Lamongan Health Center.

\section{DISCUSSION}

Respondents in this study were Fertile Age Women (WUS) aged 19-49 years totaling 77 people. Respondents are distributed based on their respective characteristics, namely from the aspects of age, education, employment, and income. Based on the results of research most users of hormonal contraception are 49 respondents $(63.6 \%)$. From this study it was found that more were not obese than obese. This shows that there is no relationship between hormonal contraceptive use and obesity. 


\section{STRADA Jurnal Ilmiah Kesehatan}

DOI: $10.30994 /$ sjik.v9i2.249

ISSN: 2252-3847 (print); 2614-350X (online)

Vol.9 No.2 November 2020 Page.964-969

The research is not in accordance with the theory which states that the use of hormonal contraception affects weight gain. As research conducted on women of childbearing age in Tasikmalaya shows that the use of contraceptives is associated with weight gain. Research on acceptors in Tasikmalaya shows that the use of various hormonal contraceptives is correlated with weight gain.

Research conducted by Sri Ratnawati et al shows that the use of implantable contraception increases the acceptor's body weight in Surabaya. In addition, the use of injectable birth control also influences weight gain, as shown by research by Finta et al in Kediri. The results of the nutritional status of women of childbearing age at the Lamongan health center were $41.6 \%$ obese and $58.4 \%$ were not obese meant that the most nutritional status was not obese. This is likely supported by high physical activity considering that most respondents are housewives. Besides education also supports this. In the study of women of childbearing age who use contraceptive pills or injections whose composition contains hormonal, both short and long term aims to control pregnancy. this use is associated with many undesirable side effects, such as irregular periods and loss of bone density. In addition, the concentration of insulin, for example in a study in Egypt in 20 women who used injection contraception for 12 months showed an increase in serum. Serum glucose levels both in the fasting state and at two hours after eating in the end the potential effects of obesity through increased levels of insulin and glucose. In this study, there was no relationship between contraceptive use and obesity $(\mathrm{P}>0.05)$.

This might be because it is influenced by a fairly high level of education and employment in this case as a housewife with quite high physical activity. Whereas in the research conducted by Lee, et al (2009) showed a significant increase in body weight with the use of medroxy progesterone acetate depot contraception (DMPA). Weight increase occurred around $3.0 \mathrm{~kg}$ for 12 months to $9.4 \mathrm{~kg}$ for 18 months. The study only focused on gaining weight. As it is known that Gonadal steroid hormone (GSH), in this case androgens, estrogens and progestins are molecules with pluripotent signaling with varied biological activities, most of which have unclear relationship between primary reproductive function and the hypothalamo-pituitary gonadal axis (HPG-axis) ). However, this study did not specify the type of hormonal contraception used with a sample of 77 people and weight gain patterns. GSH has an independent effect on weight gain and eating fat foods, including on energy expenditure and digestive function, metabolism, growth and body composition. The HPG axis has a hierarchical effect, namely: (i) hypothalamic releasing hormone GnRH (or LHRH), which synthesizes neuronal bodies cells located in the arcuate nucleus of the preoptic area, (ii) anterior pituitary hormone, FSH and LH, (iii) gonadal hormones, testosterone, estrogen and progesterone which act on a number of target tissues. Each acts as a control feedback on the function of HPG through the hipthalamus and pituitary receptors. The mechanism underlying this and its relationship to eating needs further research

The Cochrane systematic literature study also shows that there is no association between a higher body mass index (BMI) and the effectiveness of hormonal contraception. Women with a higher BMI have a higher risk of pregnancy. The risk of pregnancy with the use of hormonal contraception, especially combination oral pills, is also found to be higher in obese women than in normal weight women. The effectiveness of emergency contraceptive pills is also found to be decreased in obese women. However, the use of hormonal contraception is still better when compared to condoms or without contraception. 


\section{STRADA Jurnal Ilmiah Kesehatan}

DOI: $10.30994 /$ sjik.v9i2.249

ISSN: 2252-3847 (print); 2614-350X (online)

Vol.9 No.2 November 2020 Page.964-969

Unplanned pregnancies are found to be higher in obese women who take contraceptives with combined oral pills, however further studies are still needed. At present, long-acting reversible contraception (LARC), such as injections, implants or the IUD, is the best and safe method of hormonal contraception in obese women.

The use of hormonal contraception is also considered safe and does not affect compliance in carrying out contraceptive programs in obese women. There was no risk of further weight gain due to the use of hormonal contraception in obese women. Weight gain due to hormonal contraception is only $4 \mathrm{~kg}$ in 10 years after use and can be caused by other factors. The increased risk of thromboembolism is also considered insignificant. The use of hormonal contraception remains safe in obese women. However, the use of hormonal contraception in obese women should be re-evaluated if there is an additional risk of thromboembolism, such as cardiovascular disease, hypertension, smoking, dyslipedemia, and diabetes mellitus.

\section{CONCLUSION}

The proportion of obesity in women of childbearing age (WUS) in the Lamongan Health Center is $41.6 \%$. The most widely used type of contraception is hormonal contraception. There is no relationship between contraceptive use and obesity in women of childbearing age at the Lamongan puskesmas.

\section{SUGGESTION}

For obese people should lose weight by regulating healthy eating patterns and adequate activities, for contraceptive users in couples of childbearing age need to be held an explanation of the risk of weight gain or obesity, and further research needs to be held on the issue of the impact of hormonal contraception and the incidence of obesity

\section{REFERENCES}

Affandi B. (2010). Panduan Praktis Pelayanan Kontrasepsi (2nd ed.). Jakarta: Bina Pustaka Sarwono Prawirohardjo

Arikunto, S. (2006). Prosedur Penelitian Suatu Pendekatan Praktek. Jakarta: Rineka Cipta Cunningham FG, Leveno KJ, Bloom SL, Spong CY, Dashe JS, Hoffman BL, et al. (2014). William obstetrics. 24th ed. United States : McGraw-Hill Education; hal 704-723

Hartanto, Hanafi. (2010). Keluarga Berencana dan Kesehatan Reproduksi. Jakarta: Pustaka Sinar Harapan.

Hasan, dkk. 2013. Hubungan Penggunaan Kontrasepsi Hormonal Dengan Obesitas Pada Wanita Usia Subur (Wus) Di Puskesmas Wawonasa Kecamatan Singkil Manado.Jurnal e-Biomedik (eBM),Volume 1, Nomor 2, Juli 2013, hlm. 946-950

Hidayat, A. 2010.Metode Penelitian Keperawatan \& Teknik Analisis Data. Jakarta: Salemba Medika.

Ibrahim, Zahera. (2016). Kenaikan berat badan dengan lama pemakaian alat Kontrasepsi hormonal wilayah kerja puskesmas Pembantu sungai mengkuang. Journal Endurance (22-27). DOI : http://dx.doi.org/10.22216/jen.v1i1.591

Meilani, Niken, Dkk. 2010.Pelayanan Keluarga Berencana. Yogyakarta: Fitramaya.

Mudrikatin, S (2012). Hubungan Kontrasepsi KB Suntik 3 Bulan DMPA pada Akseptor KB dengan Peningkatan Berat Badan di Puskesmas Jabon Jombang.Jurnal Sains Med., Vol. 4. No. 1, Juni 2012: 17-22. 


\section{STRADA Jurnal Ilmiah Kesehatan}

DOI: $10.30994 /$ sjik.v9i2.249

ISSN: 2252-3847 (print); 2614-350X (online)

Vol.9 No.2 November 2020 Page.964-969

Nirwana, dkk. 2013. PengaruhPenggunaan Kontrasepsi Hormonal Terhadap Perubahan Berat Badan Akseptor Kb Di Rsia Pertiwi Makassar. Volume 1 Nomor 2 Tahun 2012

Notoatmodjo, S. 2012. Metodologi Penelitian Kesehatan. Jakarta: Rineka Cipta.

Pinem, S. 2014. Kesehatan Reproduksi \& Kontrasepsi. Jakarta: Trans Info Media.

Proverawati, A, dkk. 2010. Panduan Memilih Kontrasepsi. Yogyakarta: Nuha Medika.

Setiyaningrum, E \& Zulfa, A. 2014. Pelayanan Keluarga Berencana \& Kesehatan Reproduksi. Jakarta: Trans Info Media.

Sriwahyuni, E \& Wahyuni, CU. 2009.Hubungan antara Jenis dan Lama Pemakaian Alat KontrasepsiHormonal dengan Peningkatan Berat Badan Akseptor, The Indonesian Journal of Public Health, Vol. 8, No. 3 Maret 2012: 112-116.

Sukarni, Icemi \& Wahyu, P. 2013. Buku Ajar Keperawatan Maternitas. Yogyakarta: Nuha Medika.

Suratun, dkk. 2008. Pelayanan Keluarga Berencana dan Pelayanan Kontrasepsi. Jakarta: TIM.

Sujiyatini \& Arum, D. 2011. Panduan Lengkap Pelayanan KB Terkini. Yogyakarta: Nuha Medika.

Varney,H,dkk.2007. Buku Ajar Asuhan Kebidanan, Edisi 4, Volume 1. Jakarta: EGC.

Yuhedi, LT \& Kurniawati, T. 2014. Buku Ajar Kependudukan dan Pelayanan KB. Jakarta: EGC 